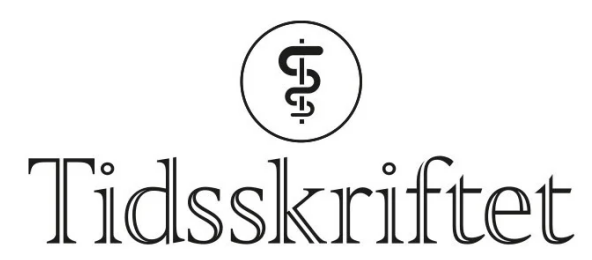

DEN NORSKE LEGEFORENING

\title{
God tannhelse for alle
}

DEBATT

TORDIS SØRENSEN HØIFØDT

tordis.sorensen.hoifodt@unn.no

Tordis Sørensen Høifødt er spesialist i psykiatri, pensjonist og tidligere klinikksjef ved Psykisk helseog rusklinikken, Universitetssykehuset Nord-Norge, der hun nå har deltidsstilling.

Forfatteren har fylt ut ICMJE-skjemaet og oppgir ingen interessekonflikter.

\section{Bedre støtteordninger må til for å gi sårbare pasientgrupper nødvendig tannbehandling.}

Tannhelse er en viktig del av den fysiske helsa. Selv om befolkningens tannhelse er blitt klart bedre de siste 30-40 årene, hovedsakelig på grunn av fluorinntak, bedret daglig munnhygiene og $\emptyset \mathrm{kt}$ generell levestandard $(\underline{1}, \underline{2})$, har enkelte grupper fortsatt større behov for tannhelsetjenester enn resten av befolkningen. Dette gjelder blant annet barn og voksne med funksjonshemning, kreftpasienter og pasienter med psykisk lidelse eller rusavhengighet. Sistnevnte gruppe har dårligere tannhelse enn befolkningen for øvrig (3, 4).

Man har sett sammenheng mellom dårlig tannhelse og $ø \mathrm{kt}$ forekomst av hjerte- og karsykdom, diabetes, kreft og luftveissykdommer (5). I tillegg kan dårlig tannstatus påvirke tyggefunksjon og tale og bidra til dårlig selvbilde, som igjen kan begrense sosial fungering. Man må ikke undervurdere hvilken betydning tannhelse har for livskvaliteten.

For alvorlig psykisk syke pasienter kan dårlig kosthold, røyking, alkohol og rusmiddelbruk forårsake tannproblemer. I tillegg kan en rekke medikamenter ha bivirkninger relatert til munnhulen, som svekket spyttproduksjon, og dårlig munnhygiene kan være en viktig tilleggsfaktor. Tannbehandling er dessuten kostbart, og det er godt dokumentert at lav sosioøkonomisk status er relatert til dårlig tannhelse $(\underline{6}, 7.7$.$) . Manglende betalingsevne og$ begrenset tilgang til tannhelsetjenester kan derfor være viktige årsaker til dårlig tannhelse i denne pasientgruppen.

\section{«Flere tiltak må til for å sikre rettigheter og bedre økonomiske støtteordninger for pasienter med spesielt dårlig tannhelse»}

$\emptyset$ konomiske støtteordninger for tannbehandling er i dag regulert gjennom tannhelsetjenesteloven og folketrygdloven. Pasienter kan også ha rett til økonomisk stønad til tannbehandling fra $\mathrm{Nav}(\underline{8-10})$. Selv om det innvilges stønad til tannbehandling, kan pasienten likevel måtte betale høy egenandel på grunn av fri prisfastsettelse i 
tannhelsetjenesten. Regelverket er i dag komplisert og forutsetter kunnskap, interesse, pågåenhet og utholdenhet hos den enkelte behandler og tannlege for at utsatte pasientgrupper skal sikres finansiering av nødvendig tannbehandling. Det er grunn til å anta at kostnadene representerer en vesentlig hindring for at pasienter får nødvendig oppfølging og tannbehandling.

I 2020 løftet Verdens helseorganisasjon (WHO) fram oral helse som en viktig - og ofte forebyggbar - utfordring for den globale folkehelsa (11). Det er positivt at tannhelse også har blitt et tema i den politiske debatten i Norge. Flere tiltak må til for å sikre rettigheter og bedre økonomiske støtteordninger for pasienter med spesielt dårlig tannhelse. Dette gjelder særlig pasienter med alvorlig psykisk lidelse og rusavhengighet.

\section{«Lcerestedene må sørge for at leger og tannleger blir bedre til å samarbeide for å sikre god tannhelse for alle pasienter»}

Legeutdanningen bør styrkes slik at studentene blir bedre kvalifisert i undersøkelse av munnhule og tenner og får mer kunnskap om hva som kan være nødvendige videre tiltak ved dårlig tannstatus. Samarbeidet mellom leger, tannhelsetjenesten, psykologer og hjemmesykepleie må styrkes. Det er lenge siden medisin og odontologi ble etablert som egne, atskilte fag. Likevel inngår inspeksjon av munnhule og tenner i mange legeundersøkelser, og det forutsetter tilstrekkelig kompetanse i munn- og tannhelse. Studieopplegget ved de medisinske og odontologiske lærestedene må sørge for at leger og tannleger blir bedre til å samarbeide for å sikre god tannhelse for alle pasienter.

\section{LITTERATUR}

1. Holst D, Schuller AA. Oral health changes in an adult Norwegian population: a cohort analytical approach. Community Dent Oral Epidemiol 2000; 28: 102-11. [PubMed][CrossRef]

2. St.meld. nr. 35 (2006-2007). Tilgjengelighet, kompetanse og sosial utjevning - Framtidas tannhelsetjenester. https://www.regjeringen.no/no/dokumenter/Stmeld-nr-35-2006-2007-|id475114/ Lest 2.9.2021.

3. Haugbo HO, Storhaug K, Willumsen T. Rusavhengighet, psykiatri og oral helse; rapport fra et sykehusprosjekt i Oslo. Den norske tannlegeforenings tidende 2010; 120: 912-7.

4. Kisely S, Baghaie H, Lalloo R et al. A systematic review and meta-analysis of the association between poor oral health and severe mental illness. Psychosom Med 2015; 77: 83-92. [PubMed][CrossRef]

5. Chapple IL. The impact of oral disease upon systemic health-Symposium overview. J Dent 2009;37: S568-71. [PubMed][CrossRef]

6. Petersen PE, Kwan S. Equity, social determinants and public health programmes-the case of oral health. Community Dent Oral Epidemiol 2011;39:481-7. [PubMed][CrossRef]

7. Molarius A, Engström S, Flink H et al. Socioeconomic differences in self-rated oral health and dental care utilisation after the dental care reform in 2008 in Sweden. BMC Oral Health 2014; 14: 134. [PubMed][CrossRef]

8. LOV-1983-06-03-54. Lov om tannhelsetjenesten (tannhelsetjenesteloven). https://lovdata.no/dokument/NL/lov/1983-06-03-54 Lest 2.9.2021.

9. Lov om folketrygd (Folketrygdloven). Rundskriv Hovednr. 35- Lov om sosiale tjenester i NAV 2001.

10. Rundskriv I-8/2017 Regelverk og takster vedrørende stønad til dekning av utgifter til tannbehandling for 2018 - revidert 16. februar 2018.

https://www.regjeringen.no/no/dokumenter/rundskriv-i-72017-regelverk-og-takster-vedrorendestonad-til-dekning-av-utgifter-til-tannbehandling-for-2018/id2582852/ Lest 2.9.2021.

11. World Health Organization. Oral health. Fact sheet. https://www.who.int/news-room/factsheets/detail/oral-health Lest 2.9.2021.

Publisert: 10. september 2021. Tidsskr Nor Legeforen. DOI: 10.4045/tidsskr.21.0597

Mottatt 18.8.2021, godkjent 2.9.2021. 
(C) Tidsskrift for Den norske legeforening 2023. Lastet ned fra tidsskriftet.no 26. april 2023. 